\title{
DISCOURSE OF NON-HETERONORMATIVE LABELLING IN GERMAN-LANGUAGE PRESS: THE CASE OF GENDERSTERNCHEN
}

\author{
Vít KOLEK \\ Palacký University Olomouc
}

Kolek, V. (2019). Discourse of Non-Heteronormative Labelling in German-Language Press: The Case of Gendersternchen. Slovenščina 2.o, 7(2): 118-140.

DOI: https://doi.org/10.4312/slo2.0.2019.2.118-140

\begin{abstract}
The Gendersternchen (*), German for gender star or gender asterisk, is one of the means available in the German language for referring to non-heteronormative persons. The aim of the present article is to analyse this discourse, i.e. the topoi and the arguments employed in the German-language newspaper articles addressing the gender star. In total, four sub-topics were delimited in order to be further analysed: the fact that it was voted Anglicism of the Year 2018; talks of the Council for German Orthography dealing with the codification of the term; general texts dealing with gender-fair language; and the introduction of gender-fair language by the Hannover local authorities. The conclusions of the discourse analysis can be relevant for a further comparative study of Slavonic languages, e.g. Czech and Slovene, where the asterisk sign and other means of highlighting non-heteronormative persons have also begun to appear.
\end{abstract}

Keywords: Gendersternchen, German, non-heteronormative labelling

1 GENDERSTERNCHEN AS A MEANS OF MAKING VISIBLE NON-HETERONORMATIVE IDENTITIES DISCURSIVELY

Since the 1980 , German feminist linguistics has provided various examples of gender-fair language. These have been further developed and are discussed in many handbooks of gender-fair language (e.g. AG Feministisch Sprachhandeln der Humboldt-Universität zu Berlin et al. 2015; Hornscheidt 2012, etc.). 
In connection with the gradual development of Queer Theory, Queer Linguistics and the emancipation efforts of transgender and intersexual groups, several ways of making visible non-heteronormative identities have also been created. It is possible to see this process from the perspective of human rights or equal opportunities, but also based on the principles of democracy, morality and ethics.

H. Motschenbacher (2014) deals with the analysis and assessment of existing means of such expression in the German language from the perspective of their capability and suitability when labelling the non-heteronormative identities. More recently, and in terms of a Czech-German comparison, this topic is dealt with by V. Kolek (in print). One of the methods which is becoming gradually more common is the use of the Gendersternchen. ${ }^{1}$ Originally a computer typographic symbol of a star $\left(^{*}\right)$ - asterisk - this is now inserted between the masculine and feminine ending -in (Schüler*in), or -innen (Schüler*innen) in plural.

This term gained much publicity in the year 2018. Since gender-fair language causes heated discussions not only in the German-speaking world (which take place in media as well), the author considers the discourse analyses of these discussions essential for understanding the frequently negative attitude towards gender-fair language. As shown by V. Kolek (2018), German periodicals do not describe gender-linguistic topics in only objective and neutral terms - and therefore, they discursively strengthen the negative attitudes towards gender-fair language.

\section{METHODOLOGY}

The aim of the present article is to analyse the discussion of the term Genderstern/Gendersternchen in the German press in a discourse-linguistic manner. In order to perform the analysis, the author extracted newspaper articles which contain one of the aforementioned terms using the search engines of German supraregional daily newspapers. In total, 145 articles which were published before the end of May 2019 were found, with the exact numbers of articles from the individual periodicals presented in Table 1 below.

1 There are also other names, such as Genderstern or more rarely Gender Star. 
Table 1: Numbers of articles by periodicals.

\begin{tabular}{|c|c|}
\hline Periodical & Number of articles \\
\hline Bild & 3 \\
\hline Börsen-Zeitung & 0 \\
\hline Frankfurter Allgemeine Zeitung & 32 \\
\hline Frankfurter Rundchau & 7 \\
\hline Handelsblatt & 2 \\
\hline Junge Welt & 4 \\
\hline Neues Deutschland & 13 \\
\hline Süddeutsche Zeitung & 25 \\
\hline Die Tageszeitung & 34 \\
\hline Die Welt & 25 \\
\hline
\end{tabular}

Selected supraregional periodicals have different political orientations which may result in certain attitudes and approaches to the focal topic of this research. This is the reason why the author briefly describes individual periodicals from that perspective. As shown by Table 1, the majority of texts comes from Die Tageszeitung, which may be labelled as a left-wing daily newspaper that supports the German Green Party, and from Frankfurter Allgemeine Zeitung, which is considered centre-right and a liberal conservative periodical. A large number of texts containing a word Genderstern/chen was also found in the centre-left Süddeutsche Zeitung and rather conservative Die Welt. On the other hand, a business daily newspaper, Handelsblatt, and a tabloid newspaper, Bild, had the fewest examples.

Firstly, the obtained articles were subjected to topic analysis. The articles dealing with the gender star on the meta-linguist level (i.e. as a means to label non-heteronormative persons) were subjected to further research (see chapters 3.1 - 3.3.1). In those articles, various topoi and argumentation patterns were qualitatively identified. Additionally, their relation to either proor con- argumentation was researched. Wengeler (e.g. 2015) deals with the term topos and its practical usage in discourse linguistics and states that "ein Topos [ist] erst dann argumentativ relevant, wenn der gesellschaftlich allgemein vorhandene und vom Individuum internalisierte Bedeutungs- und Sinnhorizont eines in unterschiedlichen Richtungen und für verschiedene Zwecke auslegbaren Topos (...) in der konkreten Kommunikationssituation von sprachlich Handelnden aufgrund ihrer eigenen Interessen, Intentionen und Zwecke realisiert, aktualisiert wird" (p. 49-50). This means that a topos 
is argumentatively relevant only since there is a generally social and by an individual internalized horizon of the meaning and sense of the variously interpreted topos (which may be used for various reasons) in concrete communication situations - while it is realized and updated by the speakers based on their own intentions and purposes.

Those very intentions and their purpose for the argumentations for or against the gender star are analysed in the present article. Spitzmüller and Warnke (2011) include topoi analysis in the "zentralen und erfolgreichen Konzepten der transtektuell orientierten Linguistik" ('central and successful concepts of the transtextually oriented linguistics'; p. 191). The author based their theory of argumentation on the classification of arguments by Eemeren and Grootendors (2004).

The articles which did not include a meta-linguistic discussion of the gender star, but which still contained at least one of the searched terms, were excluded and the author focused only on those texts whose primary topic was the non-heteronormative expression-i.e. the word Genderstern/chen. A brief examination of the excluded texts, however, shows us certain tendencies in the usage of the word Genderstern/chen. In politically oriented articles, Genderstern/chen is linked with the Green Party (Die Grünen) or with Social Democratic Party of Germany (Sozialdemokratische Partei Deutschlands), while the criticism of the term and also a general criticism of gender-fair language is linked with the right-wing extremist party Alternative for Germany (Alternative für Deutschland). Elsewhere, the previous usage of the asterisk in the names and logotypes of firms is also pointed out.

\section{ANALYSIS OF ARTICLES WITH THE PRIMARY TOPIC OF GEN- DERSTERN/CHEN}

In this part of the article, the author addresses the individual sub-discourses contained in the newspaper texts with the primary topic of the term Genderstern/chen. These include articles dealing with the fact that the term Gendersternchen was voted Anglicism of the Year 2018 and those discussing the talks of the board of Council for German Orthography (Rat für die deutsche Rechtschreibung) on the introduction of the asterisk into the official handbooks. In the following part, the newspaper texts dealing with gender-fair language 
in general will be analysed. The author has chosen the media response to the action of the Department of Women and Equality (Referat für Frauen und Gleichstellung) of the Hannover local authorities as a sub-discourse to be further analysed. More specifically, based on a document called Recommendations for the gender-fair language of city authorities (Empfehlungen für eine geschlechtergerechte Verwaltungssprache), the department has demanded the use of inclusive language in official business since 2019.

\subsection{Gendersternchen is Anglicism of the Year 2018}

Some of the articles report that the term Gendersternchen was voted Anglicism of the Year for 2018. ${ }^{2}$ This event is mostly presented in just a descriptive way - particularly with the use of many quotations from the official website of the Anglizismus des Jahres initiative. These articles (just as the quoted source) deal with the usage and purpose of the asterisk sign, germanising of the (former English) term Gender Star and its rapid acceptance and the spread of the word Gendersternchen. All of these facts provided the board of the initiative (including professor A. Stefanowitsch) with reasons to name this word Anglicism of the Year.

Since the newspaper articles follow on from the abovementioned official report when dealing with this topic, and since the chairman of the Anglizismus des Jahres initiative is a supporter of gender-fair language, the texts dealing with the topic may seem rather shallow; however, they provide objective pieces of information about the conveyed facts and also implicitly support the use of gender-fair language. In the texts it is therefore possible to consider the appeal to authority as the main type of argumentation (while using additional types of pro-argumentation). This may be, for example, "sprunghafte Verbreitung im öffentlichen Sprachgebrauch" ('rapid spreading in the public language usage'; Die Welt 1) which refers to the extensive spreading of the word, ${ }^{3}$ or "eine klare Bereicherung des deutschen Wortschatzes" ('a clear enrichment of the German vocabulary'; Bild 1). The asterisk sign is therefore presented as

2 The term framing came second and nice came third.

3 According to the official report of the Anglizismus des Jahres initiative, the number of occurrences of the term Gendersternchen rose from 0.25 to 2.5 occurrences in 10 million words. 
a positive thing, not as a Verhunzung ('a spoilage') or even Vergewaltigung der deutschen Sprache ('a rape of the German language'), which are typical in some texts dealing with gender-fair language.

The discursive purpose of the use of the asterisk sign itself varies in these texts. The following formulations are used:

a) In the texts based on the report by the Anglizismus des Jahres initiative: "um neben Männern und Frauen auch Menschen mit anderer geschlechtlichen Identität miteinzubeziehen und sichtbar zu machen." ('in order to make visible not only men and women, but also persons with other gender identities.'; Die Tageszeitung 1). This formulation is an adverbial clause of purpose, which is shortened by an infinitive to emphasize the fact that, apart from women and men, there are also persons with a different gender identities within society - and by using the asterisk sign these are included into the language, and hence made visible.

b) "So ermöglicht es, auch Menschen anzusprechen, die sich in der binären Geschlechterordnung (Frau - Mann) nicht wiederfinden." ('By doing so, it enables addressing people who cannot find themselves in the binary system (woman - man).'; Neues Deutschland 1). This formulation emphasizes the potential to address even those people beyond the binary scheme, and together with the choice of the verb sich wiederfinden (Duden 1) emphasizes one's own self-identification with one's gender. The indicative in the first part of the sentence helps to present this statement as a fact.

c) It is, however, different at the last formulation: "Der Stern soll es ermöglichen, alle Geschlechter zugleich anzusprechen.” ('The gender star should enable addressing all genders at one go.'; Die Welt 1). The choice of the modal verb sollen means (apart from the reproduction of another person's opinion) also that the speaker wants to keep a certain distance from the opinion (cf. "So ermöglicht es" and "Der Stern soll es ermöglichen"). In the formulation, the purpose of using a gender star is seen in the possibility of "addressing all genders", although the fact that those are genders beyond the binary scheme is not mentioned. For some readers, "all genders" may mean only men and women. 


\subsection{Gendersternchen as an official way to gender the text?}

Another event which was reflected in German media was the talks of the board of the Council for German Orthography (Rat für die deutsche Rechtschreibung). This council received a question from the authorities in Berlin, who asked which means of gender-fair language is the most suitable to label non-heteronormative persons. The basis for that was provided by the decision of the Constitutional Court (Verfassungsgericht) dealing with the possibility of including the sex divers on IDs. The council discussed the initiative and decided to observe the current tendencies and usage in German-speaking countries.

The Council for German Orthography states: "Dennoch ist das Recht (sic) der Menschen, die sich weder dem männlichen noch dem weiblichen Geschlecht zugehörig fühlen, auf angemessene sprachliche Bezeichnung ein Anliegen, das sich auch in der geschriebenen Sprache abbilden soll (sic)." ('Nevertheless, the right (sic) of people who do not consider themselves belonging to neither masculine nor feminine gender to be addressed adequately is still a request that should (sic) be reflected also in the written language.'; Rat für die deutsche Rechtschreibung). During their talks, the council delimited the criteria which a suitable means of gender-fair language in German should meet. According to the council, such language should:

- sachlich korrekt sein

- verständlich und lesbar sein

- vorlesbar sein (mit Blick auf die Altersentwicklung der Bevölkerung und die Tendenz in den Medien, Texte in vorlesbarer Form zur Verfügung zu stellen)

- Rechtssicherheit und Eindeutigkeit gewährleisten

- übertragbar sein im Hinblick auf deutschsprachige Länder mit mehreren Amts- und Minderheitensprachen

- für die Lesenden bzw. Hörenden die Möglichkeit zur Konzentration auf die wesentlichen Sachverhalte und Kerninformationen sicherstellen.

o ('be factually correct

o be understandable and readable 
o be readable aloud (regarding the age development of the population and the trend of the media to present texts which are in a form that might be read aloud)

o provide legal security and unambiguity

o be transferable, regarding the German-speaking countries with more than one official language and minority languages

o ensure that the readers or listeners are able to focus on the key facts and crucial "information"; Rat für die deutsche Rechtschreibung).

The newspaper articles address the introduction of the asterisk sign in various ways: "Eingang in den Duden" ('accepting in Duden'; Frankfurter Rundschau 1), "Einzug in die offizielle deutsche Rechtschreibung" ('Moving into the official German ortography'; Die Tageszeitung 2) or even "Druck zur Einführung des Gendersterns" ('the pressure to introduce the gender star'; Frankfurter Allgemeine Zeitung 1). The expression "Einzug [finden]" may be considered stylistically neutral, however, as indicated by Duden (Duden 2) and explicitly stated by Wiktionary (Wiktionary) - it also has certain military and invasive connotations which may have a negative impact. The phrase "Druck [ausüben]" expresses the pressure which was exerted to introduce the asterisk sign. By doing so, the article refuses to link the decision of the Constitutional Court to the talks of Council for German Orthography, since the Constitutional Court was supposedly not dealing with gender-fair language at all. On the other hand, the statements "Genderstern kommt vielleicht in den Duden" ('the gender star will come into Duden'; Frankfurter Rundschau 1) or “Er [Der Rat für die deutsche Rechtschreibung] könnte beschließen, das Gendersternchen offiziell ins deutsche Regelwerk aufzunehmen." ('The Council for German Orthography should decide that the gender star will be introduced into the German language rules.'; Süddeutsche Zeitung 1) which was used in an article by H. Lobin and D. Nübling dealing with German linguistics, and is stylistically neutral. Both of the statements express the estimation or assumption formulated by the adverbial "vielleicht" ('maybe') or by the subjunctive mood "könnte" ('could').

Additionally, the newspaper articles mention the statement of the Council that "Die Erprobungsphase verschiedener Bezeichnungen des dritten Geschlechts verläuft in den Ländern des deutschen Sprachraums unterschiedlich schnell 
und intensiv." ('The testing stage of various markings of the third gender is under way in German speaking countries, however, at various paces and intensities.'; Handelsblatt 1), and “kontrovers” ('controversial'; Die Welt 2), and, therefore, it is not possible to state "klare Präferenz" ('a clear preference'; Junge Welt 1). The Council therefore demands a certain homogeneity, both within the language used in individual German-speaking countries and also when choosing proper linguistic devices to label persons. However, the individual means of gender-fair language in German refer to various sub-discourses of language gender fairness (see AG Feministisch Sprachhandeln 2015; Wetschanow 2017). This makes the whole situation even more complicated. Since the individual means compete with each other in the relevant discourse (cf. e.g. Pflegerinnen und Pfleger, Pflegekräfte/Pflegepersonal and Pfleger*innen), it is not expected that one of these will assert itself to the detriment of the others. Quite the contrary, in fact, as this variety supports both more creative and precise expression. Reisigl and Spieß (2017) consider the so-called Binnen-I (e.g. PflegerInnen) acceptable for situations in which only men and women are mentioned, while they support the underscore and the asterisk sign for contexts beyond the gender binarism.

An interesting fact is that Council accepts the usage of the so-called generic masculine. ${ }^{4}$ By doing so, it ignores a number of cognitive, associative and perceptive studies analysing the masculine used generically. These studies (e.g. Hansen et al. 2016; Kusterle 2011; Stahlberg, Sczesny 2001 and many others) prove that the so-called generic masculine should not be considered a means of gender-fair language, since it does not permit any other ("nonmale") reference.

The analysed newspaper articles also mention the adverbial clause of concession: "Auch wenn der Genderstern zunehmend verwendet wird, in das Regelwerk der deutschen Sprache wird er vorerst nicht einziehen." ('Despite the fact that the gender star is used more and more, it will not be yet introduced to the German language rules'; Die Welt 2). The adverbial clauses of concession express that "ein erwarteter Kausalzusammenhang bleibt unwirksam. Der im NS [Nebensatz] genannte Grund hat nicht die nach dem Gesetz von Ursache und Wirkung zu erwartende Folge" ('a causal relation will stay ineffective.

4 This was reflected in the newspapers, e.g. Die Welt 2. 
The reason which is mentioned in the subordinate clause does not have an expectable consequence according to the rules of cause and effect.'; Helbig and Buscha 2001, p. 609). It follows that although the author of the article considers the increasing number of occurrences of labelling people using an asterisk sign as a valid reason why it should be included in the German language rules, this has not (yet) been done, due to a decision by the Council for German Orthography. As indicated by the abovementioned criteria set out by the Council, the frequency of occurrence - even if rising - is not the only reason for accepting the asterisk sign as an official orthographic means for indicating non-binary gender in a text.

\subsection{Texts dealing with the gender-fair language}

The article by H. Lobin and D. Nübling mentioned above clearly demonstrates that grammatical gender (genus) is related to biological sex (sexus), and provides details on the issue of the "generic" masculine. However, since the article is not primarily devoted to the topic of the asterisk sign this study will not pay much attention to it. A comparative overview of many of the ways used to produce gender-fair language is provided in another article (Die Tageszeitung 3).

The petition Schluss mit Gender-Unfug (Verein Deutsche Sprache) by the Verein Deutsche Sprache society received some media attention and reaction. This petition invites people to oppose the gender-fair form of language while it demands the re-enforcing of the German language. Some texts mock the topic implicitly but also explicitly. The alleged "zerstörerische Eingriffe in die deutsche Sprache" ('destructive interventions into the German language') refer both to the topos of the demise of the German language employing the argumentum ad consequentiam, and by the word "Eingriffe" (Duden 3) the society interprets this natural language development as a forced and unauthorized language intervention (cf. Mairhofer and Posch 2017).

The topos of the demise of German language is expressed metaphorically in the following statement: "Sie alle tun, als gehe es um den Verlust des Abendlandes, das in einem Meer von Gendersternchen zu versinken drohe." ('Everyone acts like it is a loss of the West which is about to drown in the sea of gender stars.'; Die Tageszeitung4). This topos is satirically responded to in the following statement: "Und zerstören lassen können wir uns unser Deutsch 
nicht. Schon gar nicht durch Weiber oder Leute, die nicht mal genau wissen, welchem Geschlecht sie sich zuordnen lassen." ('And we cannot let our German to be destroyed. Definitely not by women and people who do not even know which gender they should be counted as.'; Neues Deutschland 2). It is, however, necessary to state that the expression "Weib, -er" is in contemporary German considered outdated and pejorative (Duden 4).

Moreover, the linguist C. Posch responded critically to the petition in the German periodical Der Standard (Der Standard). The linguist briefly dealt with debunking the mistakes in the petition submitted by the society. Considering the number of linguists who signed it, the statement of the Germanist and director of the society, $\mathrm{H}$. Klatte, in the form of argumentum ad ignorantiam is surprising: "Niemand weiß mehr genau, wie man diskriminierungsfrei formulieren soll und was an den ursprünglichen Formen, das heißt an dem generischen Maskulinum, so ungerecht ist." ('Nobody really knows for sure how to address and formulate in a non-discriminatory manner and why are the original forms (i.e. generic masculine) considered unfair now.'; Die Tageszeitung 5). Without the society or its members dealing with the empirical proof of cognitive studies (see above) in more detail, they criticize and reject proposals for the gender-fair labelling of persons. Already the title of this interview - Genderwirrwarr beenden ('to end the gender chaos') - indicates that the society perceives the proposals for gender-fair language as promoting a form of chaos that they do not understand (cf. Wirrwarr; Duden 5). Therefore, even the following subjective assessments of the appearance of the asterisk sign, as expressed by the society, are not surprising: "seltsame[r] Gender-Stern" ('strange gender star') in the petition mentioned above, or: "[Ein Gendersternchen ist] im Prinzip auch nix anderes als fünf Deppenapostrophe in kreisförmiger Anordnung." ('The gender star is actually nothing more than dumb apostrophes in a circle.'; Süddeutsche Zeitung 2).

Apart from those note above, other negative and expressive phrases, e.g. Gender-Dschihad ('Gender-Jihad'; Die Tageszeitung 6) or Gender-Gaga ('Gender-Gaga'; Frankfurter Allgemeine Zeitung 2), are present in the analysed texts. The phrase Gender-Dschihad, which obviously refers to spread of Islam (Duden 6), is used in a negative connotation for the spreading of gender topics. Moreover, the phrase Gender-Gaga is used in a negative way since, the 
word gaga labels something nonsensical, without relation to reason (Duden 7). The already traditional phrases Genderwahn ('Gender delusion') or Genderwahnsinn ('Gender madness') have similar connotations. Frequently, these negative labels occur in the titles of newspaper articles to catch readers' attention, and thus it is possible to assume the negative attitude of the article already based on the title itself. This often seems paradoxical, particularly in the article by the feminist linguist L. F. Pusch (Bild 2).

In general, the founder of German feminist linguistics - L. F. Pusch - deals with non-heteronormative labelling in the form of asterisk sign. (Die Tageszeitung 7). They state that the use of the asterisk does not make the German language more gender-fair: "Der Genderstern zerreißt das Wort in drei Teile: männlicher Stamm - Genderstern - weibliche Endung." ('The gender star will tear the word into three parts: masculine stem - the gender star itself-feminine suffix.'). By this metaphor, which may be interpreted also as a forced division of words (Duden 8), the linguist expresses their negative attitude to the use of the asterisk sign. This attitude also manifests itself in other parts of the text: the queer community "[begann] die deutsche Sprache nach ihren Bedürfnissen umzugestalten" ('began to] reshape the German language according to its needs') or "mit welchem Eifer die alte Sprache nun nicht-binären Personen angepasst werden soll." ('with which effort should the old language be modified for the non-binary persons'). They interpret the effort to be represented within the language and to reflect the real structure of society in the language as a transformation of language according to one's needs or as its adjustment. Additionally, the modal verb sollen emphasizes the will of an external agent (cf. Helbig and Buscha 2001, p. 119), hence suggesting that it is not a completely voluntary move, while the linguist also emphasizes the intensity of this intention. L. F. Pusch prefers the generic feminine in their publications and media appearances; however, since they consider it unreal solution themselves, they promote the so-called Binnen-I, which is close to the generic feminine in terms of graphics and it does not allow the hierarchizing interpretations.

In the published responses from the readers' community, it is possible to find other negatively formulated reactions. A reader considers the asterisk sign "völlig willkürliche Eingriffe" ('totally arbitrary interventions'), and 
misinterprets it as an unsuccessful means to make women visible within the language - however, this is not the purpose of the asterisk sign (Süddeutsche Zeitung 3). Another reader states that if they see gender-fair language within a text they will stop reading it closely and just skim it (Neues Deutschland 3).

In several articles there are also phrases containing the word Genderstern/ chen together with an assessing attribute. Genderstern/chen is then labelled as "revoluzionär" ('revolutionary'; Süddeutsche Zeitung 4), or even more negatively as "bescheuert" ('stupid'; Die Welt 3); it is linked elsewhere with the attribute "niedlich" ('cute'; Frankfurter Allgemeine Zeitung 3), expressing rather positive or even ironizing connotations.

\subsubsection{Hannover introduces gender-inclusive language}

The specific sub-discourse of gender-fair language of Empfehlungen für eine geschlechtergerechte Verwaltungssprache of the City of Hannover comprises media reflections published at the beginning of the year 2019 (Hannover). In these recommendations, the Hannover city authorities introduced the official language which should not discriminate against anyone (including persons beyond the binary scheme woman - man). This should be accomplished by the use of neutral forms of various types; if there is no way to create such a form, they recommend to use the asterisk sign.

The newspaper articles on this story tend to comment on the situation in various ways: from the plain "einführen" ('to introduce'; Die Welt 4) and "Vorsto $\beta$ der Stadt Hannover für eine geschlechtegerechte Verwaltungssprache” ('an initiative of the City of Hannover of a gender-fair administrative language'; Die Welt 5) or "Beschluss, künftig nur noch geschlechtergerechte Sprache anzuwenden" ('a decision to use only the gender-fair language in the future'; Die Welt 6) to "Direktive" ('a directive'; Die Tageszeitung 8) (cf. Empfehlungen in the title), "kommunale Sprachreform" ('municipal language reform'; Die Welt 6) or "Krieg in der niedersächsischen Landeshauptstadt" ('War in a Lower Saxon capital'; Die Tageszeitung 9). It is possible to deduce the attitudes of the individual articles and their authors based on the titles alone.

This event was also discussed in the media by linguists. The author analyses here the reactions by H. Glück and L. F. Pusch. H. Glück, one of the 
signatories to the petition Schluss mit dem Gender-Unfug mentioned above, states in their provocatively named article Die Ersatzreligion der sprachlichen Anbiederung ('The substitute religion of the language curry favour'; Frankfurter Allgemeine Zeitung 4) that Hannover is ignoring the results of grammatical research. According to Glück, grammar books should be united on the stance that "das grammatische Geschlecht, das Genus, mit dem natürlichen Geschlecht, dem Sexus, nicht viel (sic) zu tun hat." ('the grammatical genus is not that much (sic) similar to the natural sex.') U. Doleschal (2002) presented the diachronous analysis of generic masculine's codification in German grammar books. By this formulation, H. Glück makes the presumption that the whole situation is unambiguous and all linguists are united on this matter. However, even if the grammar books were united in this matter, this would only say something about their authors and attitudes, not about the real perception of the generic masculine, research on which is ignored by H. Glück.

Furthermore, the linguist states that the asterisk sign breaches the rules of German orthography, since these allow only brackets and a slash out of the broad range of ways to express gender-fair language. Therefore, H. Glück uses the status quo to employ argumentum ad antiquitatem. This argument may be considered particularly suspect, since this discussion was preceded by the talks of Council for German Orthography (see above). In terms of the asterisk sign, Glück fails to avoid the slippery slope argument since they state that this will make a lot of work for the Hannover authorities with regard to renaming the streets and city quarters, as well as the renaming of persons while using the asterisk.

In their article (Die Welt 5), L. F. Pusch appeals to the emotions (argumentum ad passiones) with the statement: "Ich bedaure die Einführung des Gendersterns durch meine Heimatstadt Hannover." ('I regret the introduction of the gender star by my hometown, Hannover.'), while they express not only their sadness but also use the topos of patriotism. They state that "die Frauen finden sich als Anhängsel wieder, wie zu Anfang der feministischen Sprachkritik.” ('the women will find themselves again as an appendage, as they were in the beginning of the feminist language criticism.'). With the word "Anhängsel” they emphasize the alleged inferiority and redundancy of women in labels containing the asterisk sign. They consider this a return to the beginning of 
feminist linguistics. The author, however, argues that L. F. Pusch overlooks the "added value" of discursively making visible non-heteronormative persons while also preserving the visibility of women within the language. The forms containing asterisk signs are linguistically more economic than the double (and heteronormative) forms. It is also possible to mention the linguistic response by G. Diewald (Süddeutsche Zeitung 5), who holds the contrary opinion while stating that people will get used to the asterisk just as they have got used to smileys or the euro sign ( $€$ ).

Other German cities also responded to the recommendation from Hannover. While Augsburg does not use the "generic" masculine, it also rejects the asterisk sign, since it does not meet the rules of German orthography. ${ }^{5}$ On the other hand, the Stuttgart authorities are in favour of using an asterisk for even more words e.g. "Mädchen*" ('a girl') or "Junge *" ('a boy'), as this can indicate the non-stereotypical understanding of these categories (Die Welt 6). Therefore, it is likely that other cities will make similar decisions in the near future.

The usage of gender-fair language in the school environment is put into context together with the Hanoverian recommendations, as seen in some of the articles analysed here. One of them states that The German Education Union (Gewerkschaft Erziehung und Wissenschaft) has decided that children should be exposed to gender-fair language (Süddeutsche Zeitung 6). It is, however, not clear what is meant by this statement and if they would be obliged to use gender-fair language themselves. The author of the article, however, uses the "generic" masculine when stating that "es sei gut, wenn Lehrer gendergerechte Sprache verwenden." (it is good when the teachers ${ }_{\text {MASC }}$ use the gender-fair language'.)

Another text reflects on the need for gender-fair language in the school environment (Bild 3). The teachers asked about such a need all responded negatively: "So lange die Wörter nicht explizit im Duden stehen, mache ich das nicht." ('I will not do it until these words are in Duden explicitly.') or: "Schon wieder eine Neuerung, kann man denn überhaupt nicht mehr in Ruhe

5 The author considers it necessary to mention that some newspapers, and mainly texts of a scientific nature, use the asterisk sign. The fact that the asterisk is not an official means of expressing gender is not considered by the authors of such publications an obstacle to its use. 
arbeiten?" ('So, another novelty? Can one just work in peace for once?'). The first response perhaps relates to the debated codification of the asterisk sign. However, it must be pointed out that it is not necessary to codify many other of the available means (e.g. double forms, participles, etc.), because they were created based on the available German language material. The second response considers the effort to introduce gender-fair language in schools as just one of many novelties which should be dealt by teachers and which make their work more difficult. Overall, the teachers consider it more important to teach their pupils grammar.

The last of the texts mentions the interview with the Lower Saxony Minister of Science and Culture (Die Welt 7). The minister thinks that schools should deal with the issue of gender-fair language on their own, without the state making the rules, but also that the use of gender-fair language should be possible in every subject.

\section{CONCLUSION}

In this study, the reaction to the term Genderstern/chen was analysed in various supraregional German periodicals with different orientations. Based on the thematic analysis, the articles were classified into four fields which constitute sub-discourses linked to the analysed term.

The fact that the word Gendersternchen was chosen as the Anglicism of the Year 2018 was discussed first. In this, the fact that most of the newspaper texts drew heavily on the official report presented by the Anglizismus des Jahres initiative was obvious.

In terms of the media reaction to Council for German Orthography and the use of the asterisk sign as an official means of expressing gender in German, an analysis of the newspaper texts shows that the official report of the Council also received much coverage. However, not all of these newspaper texts supported the proposals of the Council.

The newspaper texts dealing with gender-fair language in general or without a primary focus on non-heteronormative language at all take a rather negative stand on the issue - be it the texts from Verein Deutsche Sprache society or L. F. Pusch, a feminist linguist. These negative attitudes manifest themselves 
not only in the form of naming the gender-fair language, but also in the choice of expressive language devices, adjectives or modal verbs. It is possible to consider the media reaction to the introduction of gender-inclusive language in the offices of Hannover's authorities as a sub-topic of this sub-discourse. Again, it is possible to mention a few people criticizing the efforts of the city to include non-heteronormative persons into the language, such as H. Glück and L. F. Pusch.

Since it is a discourse which is "alive" and ongoing, some of the important issues may have only been hinted at. In the future, it is possible to expect additional reports from the talks of Council for German Orthography in the area of non-heteronormative language usage. These reports would then be reflected in the media as well as in general discussions about gender-fair language or, more specifically, about non-heteronormative labelling. It is also possible to expect further spreading of the asterisk sign in the future, which will also be reflected in the media. The usage of the asterisk sign (or the underscore) to label non-heteronormative persons is also spreading among the Slavic languages, e.g. Slovene and Czech (cf. Popič and Gorjanc, 2018, Kolek in print), and this may be a potential direction for future analyses.

\section{References}

Damm, A., Hayn, E., Hornscheidt, L., \& Weeber, S. (Eds.). (2015). Was tun? Sprachhandeln - aber wie? W_Ortungen statt Tatenlosigkeit. Anregungen zum Nachschlagen, Schreiben_Sprechen_Gebärden, Argumentieren, Inspirieren, Ausprobieren, Nachdenken, Umsetzen, Lesen_Zuhören, antidiskriminierenden Sprachhandeln. Berlin: Humboldt. AG Feministisch Sprachhandeln der Humboldt - Universität zu Berlin.

Doleschal, U. (2002). Das generische Maskulinum im Deutschen. Ein historischer Spaziergang durch die deutsche Grammatikschreibung von der Renaissance bis zur Postmoderne. Linguistik Online, 11(2), 39-70. Retrieved from https://bop.unibe.ch/linguistik-online/article/view/915/1595

Hansen, K., Littwitz, C., \& Sczesny, S. (2016). The Social Perception of Heroes and Murderers: Effects of Gender-Inclusive Language in Media Reports. Frontiers in Psychology, 7, p. 369. Retrieved from https://www. 
Helbig, G., \& Buscha, J. (2001). Deutsche Grammatik. Ein Handbuch für den Ausländerunterricht. Berlin/München: Langenscheidt KG.

Hornscheidt, L. (2012). Feministische w_orte. ein lern-, denk und handlungsbuch zu sprache und diskriminierung, gender studies und feministischer linguistik. Frankfurt am Main: Brandes \& Apsel.

Kolek, V. (2018). Studentenwerk oder Studierendenwerk? Eine diskurslinguistische Analyse. In M. Horňáček, J. Krappmann \& K. Rinas (Eds.), Vom Nutzen diskursanalytischer Verfahren (pp. 191-209). Olomouc: Univerzita Palackého.

Kolek, V. (in print). Options for Labelling non-heteronormative Persons in German-Czech Comparison. In D. Scheller-Boltz (Ed.), Language Policies in the Light of Anti-Discrimination and Political Correctness: Tendencies and Changes in the Slavonic Languages (Wiener Slawistischer Almanach, Sonderband). Frankfurt am Main: Peter Lang.

Kusterle, K. (2011). Die Macht von Sprachformen. Der Zusammenhang von Sprache, Denken und Genderwahrnehmung. Frankfurt am Main: Brandes \& Apsel.

Mairhofer, E., \& Posch, C. (2017). Die Normalität ist eine gepflasterte Straße ... Argumentationsanalytische Untersuchung eines Offenen Briefs gegen antidiskriminierenden Sprachgebrauch in Österreich. In M. Reisigl \& C. Spieß (Eds.), Osnabrücker Beiträge zur Sprachtheorie 91. Sprache und Geschlecht. Band 2: Empirische Analysen (pp. 35-57). Duisburg: Universitätsverlag Rhein-Ruhr.

Motschenbacher, H. (2014). Grammatical gender as a challenge for language policy: The (im)possibility of non-heteronormative language use in German versus English. Language Policy, 13(3), 243-261.

Popič, D. and Gorjanc, V. (2018). Challenges of adopting gender-inclusive language in Slovene. Suvremena lingvistika, 44(86), 329-350. doi: https://doi.org/10.22210/suvlin.2018.086.07

Reisigl, M., \& Spieß, C. (2017). Sprache und Geschlecht als Gegenstand der Linguistik. In C. Spieß \& M. Reisigl (Eds.), Osnabrücker Beiträge zur Sprachtheorie 9o. Sprache und Geschlecht. Band 1: Sprachpolitiken und Grammatik (pp. 7-32). Duisburg: Universitätsverlag Rhein-Ruhr. 
Spitzmüller, J., \& Warnke, I. H. (2011). Diskurslinguistik. Eine Einführung in Theorien und Methoden der transtextuellen Sprachanalyse. Berlin/ Boston: Walter de Gruyter.

Stahlberg, D., \& Sczesny, S. (2001). Effekte des generischen Maskulinums und alternativer Sprachformen auf den gedanklichen Einbezug von Frauen. Psychologische Rundschau, 52(3), 131-140.

Van Eemeren, F. and Grootendorst, R. (2004). A Systematic Theory of Argumentation. The pragma-dialectal approach. Cambridge: Cambridge University Press.

Wengeler, M. (2015). Die Analyse von Argumentationsmustern als Beitrag zur „transtextuell orientierten Linguistik“. In H. Kämper and I. H. Warnke (Eds.), Diskurs - interdisziplinär. Zugänge, Gegenstände, Perspektiven (pp. 47-62). Berlin/Boston: Walter de Gruyter.

Wetschanow, K. (2017). Von nicht-sexistischem Sprachgebrauch zu fairen W_ortungen - Ein Streifzug durch die Welt der Leitfäden zu sprachlicher Gleichbehandlung. In C. Spieß \& M. Reisigl (Eds.), Osnabrücker Beiträge zur Sprachtheorie 9o. Sprache und Geschlecht. Band 1: Sprachpolitiken und Grammatik (pp. 33-59). Duisburg: Universitätsverlag Rhein-Ruhr.

\section{Websites:}

Anglizismus des Jahres, http://www.anglizismusdesjahres.de/anglizismen-des-jahres/ anglizismen-des-jahres-adj-2018/

Bild 1, “„Gendersternchen“ ist Anglizismus des Jahres“, https://www.bild.de/ lgbt/2019/lgbt/ expertenjury-gendersternchen-ist-anglizismus-des-jahres-59824286.bild.html Bild 2, "Gender-Gaga - Wird jetzt alles noch viel schlimmer(in)?", https:// www.bild.de/regional/ hannover/hannover-aktuell/gender-gaga-wird-jetzt-alles-noch-viel-schlimmer-in-59747280.bild.html

Bild 3, "Brauchen wir Gender an der Schule?", https://www.bild.de/ratgeber/kind-familie/kind-und-familie/lehrerblog-brauchen-wir-gender-in-der-schule-60027286.bild.html

Duden 1, "wiederfinden“, https://www.duden.de/rechtschreibung/wiederfinden

Duden 2, "Einzug", https://www.duden.de/rechtschreibung/Einzug

Duden 3, "Eingriff", https://www.duden.de/rechtschreibung/Eingriff

Duden 4, "Weib", https://www.duden.de/rechtschreibung/Weib

Duden 5, "Wirrwarr", https://www.duden.de/rechtschreibung/Wirrwarr 
Duden 6, “Dschihad“, https://www.duden.de/rechtschreibung/Dschihad

Duden 7, “gaga“, https://www.duden.de/rechtschreibung/gaga_nicht_recht_bei_Verstand

Duden 8, “zerreißen“, https://www.duden.de/rechtschreibung/zerreiszen

Frankfurter Allgemeine Zeitung 1, "Noch längst nicht vom Tisch“, https://www.faz. net/aktuell/politik/inland/warum-der-genderstern-noch-nicht-vom-tisch-ist-15900573.html

Frankfurter Allgemeine Zeitung 2, “Dorothee Bär hält gendergerechte Sprache für „gaga““, https://www.faz.net/aktuell/politik/inland/csu-politikerin-dorothee-baer-haelt-gendergerechte-sprache-fuer-gaga-1607690o.html

Frankfurter Allgemeine Zeitung 3, "Der Schlüssel zu mehr Bildungsgerechtigkeit“, https://www.faz.net/aktuell/karriere-hochschule/gendergerechte-sprache-der-schluessel-zu-mehr-bildungsgerechtigkeit-16166042.html

Frankfurter Allgemeine Zeitung 4, "Hannover ignoriert die Erkenntnisse“, https://www.faz.net/aktuell/karriere-hochschule/geschlechtergerechte-sprache-hannover-ignoriert-die-erkenntnisse-16051449.html

Frankfurter Rundschau 1, "Gendersternchen kommt vielleicht in den Duden“, https://www.fr.de/panorama/gendersternchen-kommt-vielleicht-duden-10981619. html

Handelsblatt 1, "Rechtschreibrat schreckt vor Gender-Schreibweise im Duden zurück“. https://www.handelsblatt.com/politik/deutschland/genderstern-rechtschreibrat-schreckt-vor-gender-schreibweise-im-duden-zurueck/23648006. html?ticket=ST-2397663-zV59ymH6gcoICtwiAFOh-ap1

Hannover, "Empfehlungen für eine geschlechtergerechte Verwaltungssprache“, https://www.hannover.de/content/download/756032/18968385/file/Flyer_Geschlechtergerechte_Sprache.pdf

Junge Welt 1, “Keine Entscheidung fürs Gendersternchen“, https://www.jungewelt.de/artikel/334219.keine-entscheidung-f\%C3\%BCrs-gendersternchen.html

Neues Deutschland 1, "Aber bitte mit * ! Sieger*in bei »Anglizismus des Jahres«: das Gendersternchen“, https://www.neues-deutschland.de/artikel/1111206. anglizismus-des-jahres-aber-bitte-mit.html

Neues Deutschland 2, “»Dass man Sprache so verhunzt ...“, https://www.neues-deutschland.de/artikel/1114166.geschlechtergerechte-sprache-dass-man-sprache-so-verhunzt-h.html

Neues Deutschland 3, "Ihre Post an die Redaktion“, https://www.neues-deutschland.de/artikel/1089188.ihre-post-an-die-redaktion.html 
Rat für die deutsche Rechtschreibung, “Empfehlungen zur „geschlechtergerechten Schreibung“, https://www.rechtschreibrat.com/DOX/rfdr_PM_2018-1116_Geschlechtergerechte_Schreibung.pdf

Der Standard, “Der wahre Sprachunfug - eine Replik“, https://www.derstandard. de/story/2000099886356/der-wahre-sprachunfug-eine-replik

Süddeutsche Zeitung 1, "Tief in der Sprache lebt die alte Geschlechterordnung fort“, https://www.sueddeutsche.de/kultur/genderdebatte-tief-in-der-sprache-lebt-die-alte-geschlechterordnung-fort-1.4003975

Süddeutsche Zeitung 2, “Die Wanne ist voll“, https://www.sueddeutsche.de/kultur/ verein-deutsche-sprache-gender-1.4358685

Süddeutsche Zeitung 3, "Ein Sternchen, das spaltet", https://www.sueddeutsche. de /kolumne/gendergerechte-sprache-ein-sternchen-das-spaltet-1.4397933

Süddeutsche Zeitung 4,“Glückskekse statt Revolution“, https://www.sueddeutsche.de /muenchen/fuerstenfeldbruck/mitten-in-germering-glueckskekse-statt-revolution-1.3656092

Süddeutsche Zeitung 5, "Aus Hannoveranern werden Hannoveraner*innen“, https://www. sueddeutsche.de/panorama/hannover-sprache-gender-1.4299969

Süddeutsche Zeitung 6, "GEW für geschlechtergerechte Sprache schon in Schule“, https://www.sueddeutsche.de/bildung/bildung-hannover-gew-fuer-geschlechtergerechte-sprache-schon-in-schule-dpa. urn-newsml-dpa-com-20090101-190131-99-804900

Die Tageszeitung 1, “die wortkunde: Gender-Sternchen“, https://taz. de/!5565809/

Die Tageszeitung 2, “Gendersternchen auf dem Prüfstand“, https://taz.de/ Geschlechtergerechte-Sprache/!5510280/

Die Tageszeitung 3, “Gegen den Strich“, https://taz.de/!5218668/

Die Tageszeitung 4, “ Die Wirkungsmacht der Literatur“, https://taz.de/ Essay-Sprache-und-Geschlecht/!5587579/

Die Tageszeitung 5, “„Genderwirrwarr beenden“, https://taz.de/ Geschaeftsfuehrer-VDS-ueber-Gendern/!5464085/

Die Tageszeitung 6, “Gender-Dschihad geht weiter“, https://taz.de/ Kolumne-Minority-Report/!5576380/

Die Tageszeitung 7, "Eine für alle“, https://taz.de/ Debatte-Geschlechtergerechte-Sprache/!5577446/

Die Tageszeitung 8, “Hannover“, https://taz.de/!5565181/ 
Die Tageszeitung 9, “Genderkrieg in Hannover*in“, https://taz.de/ Die-Wahrheit/!5572575/

Verein Deutsche Sprache, "Schluss mit dem Gender-Unfug“, https://vds-ev.de/gegenwartsdeutsch/gendersprache/gendersprache-unterschriften/ schluss-mit-dem-gender-unfug/

Die Welt 1, “«Gendersternchen» ist der «Anglizismus des Jahres»", https:// www.welt.de/newsticker/dpa_nt/infoline_nt/boulevard_nt/article187877378/Gendersternchen-ist-der-Anglizismus-des-Jahres.html

Die Welt 2, "Rechtschreibrat: Genderstern noch in der Erprobungsphase“, https://www.welt.de/regionales/bayern/article183949444/Rechtschreibrat-Genderstern-noch-in-der-Erprobungsphase.html

Die Welt 3, "Lasst uns weniger höhnisch mit dem Feminismus umgehen“, https://www.welt.de/debatte/kommentare/article184458786/Gewalt-gegen-Frauen-Lasst-uns-weniger-hoehnisch-mit-dem-Feminismus-umgehen.html

Die Welt 4, “„Die Frauen finden sich als Anhängsel wieder““”, https://www.welt. de/politik/deutschland/article187614722/Gendersternchen-in-Hannover-Feministische-Linguistin-Pusch-lehnt-Vorstoss-ab.html

Die Welt 5, "Sprachwissenschaftlerin lehnt Vorstoß in Hannover ab“, https:// www.welt.de/regionales/niedersachsen/article187614770/Sprachwissenschaftlerin-lehnt-Vorstoss-in-Hannover-ab.html

Die Welt 6, “„Nicht zu sehr von der Alltagssprache der Menschen entfernen““”, https://www.welt.de/politik/article187755028/Gender-Verwaltung-in-Hannover-kommuniziert-geschlechtergerecht.html

Die Welt 7, “Tonne: Schulen sollen für gendergerechte verantwortlich sein“, https://www.welt.de/regionales/niedersachsen/article188133621/Tonne-Schulen-sollen-fuer-gendergerechte-verantwortlich-sein.html

Wiktionary, “Einzug“, https://de.wiktionary.org/wiki/Einzug 


\section{DISKURZ NEHETERONORMATIVNEGA OZNAČEVANJA OSEB V NEMŠKEM TISKU NA PRIMERU GENDERSTERNCHEN}

Gendersternchen $\left({ }^{*}\right)$, nem. za spolno zvezdico oz. asterisk, je eno od možnih sredstev v nemščini za naslavljanje neheteronormativnih oseb. Namen članka je analizirati diskurz, tj. topos in argumente v nemških časopisnih člankih, ki se navezujejo na ta jezikovni element. Skupno smo za nadaljnjo analizo zamejili štiri podteme: dejstvo, da gre za anglicizem leta 2018; diskusije Sveta za nemški pravopis o kodifikaciji termina; splošna besedila o spolno nevtralnem jeziku in pa uvedbo spolno nevtralnega jezika hannovrskih mestnih oblasti. Sklepi analize diskurza lahko služijo za nadaljnje komparativne raziskave slovanskih jezikov, npr. češčine in slovenščine, kjer so se začeli pojavljati asterisk in drugi jezikovni elementi za naslavljanje neheteronormativnih oseb.

Ključne besede: Gendersternchen, nemščina, neheteronormativno označevanje

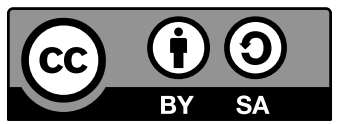

To delo je ponujeno pod licenco Creative Commons: Priznanje avtorstva-Deljenje pod enakimi pogoji 4.o Mednarodna. / This work is licensed under the Creative Commons Attribution-ShareAlike 4.0 International.

https://creativecommons.org/licenses/by-sa/4.o/ 